\title{
Eremya Çelebi Kömürciyan'ın Gözüyle İstanbul Kapıları
}

\author{
Habibe KAZANCIOĞLU *
}

\section{Özet}

Tarih boyunca şehirlerin iç güvenliğinin sağlanması kadar dışarıdan gelebilecek tehlikelere karşı güvenliğin sağlanması da önem arz etmiştir. Bu amaçla ilk ve orta çağda şehirleri dış tehlikelerden korumak için şehirlerin etrafina sağlam surlar inşa edilmiştir. Kurulduğu günden itibaren jeopolitik önemini koruyan İstanbul, sürekli dış tehlikelerle karşı karşıya gelmiş şehir, bu tehlikelerden Roma ve Bizans dönemlerinde inşa edilen surlar sayesinde korunmuştur. Şehre giriş çıkışları sağlamak için bu surların çeşitli yerlerine kapılar açılmıştır. Sur üzerinde açılan bu kapıların civarları daha önceki dönemlerde olduğu gibi Osmanlı döneminde de sosyo-ekonomik hayatın en canlı olduğu yerler olarak önemini korumuştur.

Birçok seyyah ve tarihçinin eserlerine konu olan bu kapıların civarındaki yaşantı, XVII. yüzyılda İstanbul'da yaşamış olan Eremya Çelebi Kömürciyan tarafından açıklayıcı bilgiler ve renkli tasvirlerle anlatılmaktadır.

Anahtar Kelimeler: İstanbul, sur, kap1.

* Yrd. Doç. Dr., Trakya Üniversitesi İlahiyat Fakültesi, İslam Tarihi Anabilim Dalı Öğretim Üyesi, habibekazancioglu@trakya.edu.tr

YIL: 5 SAYI: 10 


\title{
İstanbul Doors With The Eye Of Eremya Çelebi Kömürciyan
}

\begin{abstract}
Throughout history, as much as ensuring internal security of the cities, it was important to ensuring security from external hazards. To this end, in the ancient times and in the middle ages, sturdy walls has built around the cities to protect them from external hazards. City that maintains geopolitical importance since its founded the İstanbul was faced with constant external threats and it is protected through the walls built during the Roman and Byzantine periods from these threats. Gates has opened to ensure entry and exit to city in various parts of the walls. As in previous periods, in Ottoman period, the around of these gates were the places where the socio-economic life has kept its importance as the most vivid.

Life around those gates which is subjected to the works of many historians and pilgrims, are explained with descriptive information and colorful depiction by Eremya Çelebi Kömürciyan, who lived in Istanbul in the 17th century.
\end{abstract}

Keywords: İstanbul, wall, gate

\section{Giriş}

İstanbul Kapıları çeşitli araştırmalara konu olmuş birçok eserde bu konu üzerinde durulmuştur. Bu eserlerden biri de Ermeni edebiyatının önemli isimlerinden şâir ve yazar oluşunun yanı sıra tarihçi kimliği ile 


\section{6 • YALOVA SOSYAL BILIMLER DERGISI}

\section{de tanınan Eremya Çelebi Kömürciyan’11n İstanbul Tarihi ${ }^{2}$ isimli eseridir.}

1 Eremya Çelebi Kömürciyan, ataları Kafkaslar'dan göç ederek Erzincan'ın Kemah ilçesine yerleşmiş daha sonra Celali isyanları esnasında Gelibolu'ya göç eden Ermeni bir aileye mensuptur.

12 veya 13 Mayıs 1637 yılında İstanbul'un Langa semtinde doğan Eremya Çelebi, ilk tahsilini babasının meslektaşı ve aile dostu Surp Sargis Kilisesi papazlarından Der Hovannes'in yanında yapmıştır.1656 yılında Türkçe, ardından Rumca, Farsça, Arapça ve İbranice öğrenmiştir. Çocukluğu kilise muhitinde geçmesine rağmen -muhtemelen fikir ve faaliyet serbestliğini kısıtlamasından çekindiği için- ruhanîler sınıfına girmemiş ancak patrikhane kâtipliği ile kilisenin işleyişiyle ilgili çözümü güç meselelerde danışmanlık yapmıştır. Eremya Çelebi, gerek şahsiyeti gerek değişik türdeki yazıları gerekse diğer sahalardaki faaliyetleri bakımından XVII. yüzyılda yaşamış Ermeni aydınları içinde dikkate değer bir kişidir. İlim ve faziletinden dolayı kendisine "Çelebi" unvanı verilmiştir.1695 yılında İstanbul'da vefat eden Eremya Çelebi, Balıklı Ermeni Mezarlığı'na gömülmüştür.

Eremya Çelebi'nin eserleri, manzum ve mensur olmak üzere ruznâme ve vekayinâme şeklinde tarihî hadiselerin kayıtları, tarih, topografya, önemli şahsiyetlerin aile tarihleri ve şecereleri, dinî meselelere ait nutuk ve muhâvereler, aile efradına ve başkalarına dair mersiyeler, ailevî ve bilhassa cemaat işleri hakkındaki mektuplar ile hiciv mahiyetindeki hikayelerden oluşmaktadır.

Eremya Çelebi, zamanın meşhur Ermeni tacirlerinden Abro Çelebi’nin himayesini kazanmış, çocuklarına hocalık yapmıştır. Abro Çelebi, devlet ricalinin özellikle de Fazıl Ahmet Paşa (1661-1676)'nın itimadını kazanmış, Mora ve Girit seferlerinde beraberinde bulunmuştur. Böyle nüfuzlu bir zatın evi Türk ve yabancı ileri gelenlerinin bir araya gelme noktası olduğundan, Eremya Çelebi bu vesile ile birçok yüksek rütbeli devlet adamıyla tanışmış, devletle ilgili konular başta olmak üzere pek çok konuda bilgi sahibi olmuştur. Daha sonra bu bilgileri bizzat şahidi olduğu olaylarla birlikte eserlerinde kullanmıştır. Nitekim, Osman Gazi'den zamanın padişahı IV. Mehmet'e kadar ki padişahların dönemlerini konu alan Osmanlı Tarihi, Ístanbul Tarihi, İstanbul Yangını Tarihi, Ruzname ve Vekayiname bu eserlerdendir. (Eremya Çelebi ve eserleri hakkında daha geniş bilgi için bkz. Eremya Çelebi Kömürciyan, İstanbul Tarihi, Hrand D., Andreasyan (çev), İstanbul 1952; Eremya Çelebi Kömürciyan, İstanbul Tarihi, Hrand D., Andreasyan (çev), Kevork Pamukciyan (hzl.) İstanbul 1988; Kevork Pamukciyan, "Doğumunun 350.Yılında Eremya Çelebi Kömürciyan” Tarih ve Toplum, IX, 54 (Haziran 1988); Kevork Pamukciyan, "Eremya Çelebi'ye Göre İstanbul'un 1660 Yangını”, Tarih ve Toplum, XIII, 75 (Mart 1990); Kevork Pamukciyan, “Eremya Çelebi Kömürciyan'ın (1637-1695) Dörtyüz Yıllık Osmanlı Padişahları Tarihi” Müteferrika, 1995/5; Ziya Yılmazer, "Eremya Çelebi”, Diyanet Íslam Ansiklopedisi (DİA), XI)

2 Eremya Çelebi, İstanbul Tarihi (Badmutyun Isdanbol) isimli eserini 1662-1684 tarihleri arasında, aralıklarla manzum olarak telif etmiştir. Eserin üç yazması bulunmaktadır. Müellif hattı ile yazılmış metin Kudüs Ermeni Patrikhanesi'nde, bir nüshası Eçmiadzin'de diğer nüshası ise V. Torkomyan'ın özel kütüphanesinde olup bu nüsha 1913'te Viyana'da V. Torkomyan tarafından üç cilt halinde yayımlanmıştır. Aynı nüsha Hrand D. Andreasyan tarafından Türk-

YIL: 5 SAYI: 10 
Eremya Çelebi, eserinde XVII. yüzyıl İstanbul'u hakkında bilgi verirken günümüzde tarihî yarımada olarak da isimlendirilen Eski İstanbul'un kapıları ve civarındaki sosyal hayat hakkında da bilgiler vermektedir.

İlk ve Orta Çağlarda bir kasabanın bir şehrin hatta bazen bir eyaletin güvenliği çevresine "sur" adı verilen kuleli tahkîmat duvarlarıyla sağlanird1 $^{3}$

Doğu Roma İmparatorluğu ve Osmanlı Devleti’nin başşehri İstanbul, kabaca dik kenar üçgeni andıran bir yarımadanın üstüne kurulmuştur. $\mathrm{Bu}$ üçgenin diğerlerine göre daha kısa kenarını kara sınırları oluştururken diğer iki kenarını ise Marmara ile Haliç sahilleri oluşturmaktadır. ${ }^{4}$ Osmanlılar zamanında ise "nefs-i İstanbul" olarak isimlendirilen bu kesim ile Galata, Eyüp, Üsküdar ve bunlara bağlı kadılık bölgelerinden oluşan "bilâd-1 selâse" İstanbul'u oluşturmaktayd1. ${ }^{5}$

Tarihî İstanbul yarımadası, savunmada iki tarafının denizle çevrili olması bakımından avantajlı, kara tarafının düşman saldırısına açık olması bakımından da dezavantajlı coğrafî bir konuma sahipti. Şehir, sahip olduğu bu doğal özelliğine göre kurulduğu günden itibaren karadan ve denizden gelebilecek saldırılara karşı özellikle Doğu Roma ve daha sonra Bizans İmparatorları tarafından yapılan muhkem surlarla çevrelenmiş ve korunmuştur. $^{6}$

çeye tercüme edilmiş, 1952 yılında İstanbul Üniversitesi Edebiyat Fakültesi yayınları arasında çıkmıştır. Hrand D. Andreasyan tarafından Türkçeye çevrilen bu eser 1988 yılında Kevork Pamukciyan tarafından ilave notlarla yayıma hazırlanmış ve 1988 yılında basılmıştır. Andreasyan'ın tercümesini yaptığı ve sekiz bölümden oluşan bu manzum eser, “Kefe vezni” denilen heceli bir vezin ile yazılmıştır. Kömürciyan, 2053 mısradan oluşan eserini halk dili ve karışık eski Ermenice olarak kaleme almıştır. Eserin birçok yerinde Türkçe, Farsça ve Rumca kelimelere rastlanmaktadır.

Eremya Çelebi, eserini zamanın meşhur Ermeni âlimlerinden Bitlis’teki “Amırdolu Vank" manastırın Başrahibi Vardepet Vardan'ın isteği üzerine yazmış ve eserini ona ithaf etmiştir. Şehrin topografik durumunu anlatıp XVII. yüzyıl İstanbul'una genel bir bakışı ihtiva eden bu eser, şehrin başlıca mevkileri hakkında bilgi vermekte buralarda geçen bazı olayları kısa bir şekilde aktarmaktadır. (Konuyla ilgili bilgi için bkz. Eremya Çelebi Kömürciyan, İstanbul Tarihi, Hrand D. Andreasyan (çev), İstanbul 1952, ss. XXIX-XXX)

3 Semavi Eyice "Kale", DIA, XXIV, 234

4 Károly Kós, İstanbul: Şehir Tarihi ve Mimarisi, Naciye Güngörmüş (çev), Ankara 1985, s.21

5 Halil İnalc1k “İstanbul”, DIA, XXIII, 220

6 Şehrin en eski surları MÖ. 658 yılında Megara şehrinden Byzas isimli bir lider başkanlığında gelip bugünkü Topkapı Sarayı'nın olduğu civara yerleşen Yunan kökenli Trakyalı halkın, baş- 
İstanbul, bin yılı aşkın bir süre, karadan ve denizden gelen saldırılara, bu surlarla karşı koymuş bu sayede hiçbir yabancı güç içeri girememiştir. Bu tahkîmatı aşan tek askeri güç Fatih Sultan Mehmed'in idaresindeki Osmanlı ordusu olmuştur. 29 Mayıs 1453'te Fatih Sultan Mehmed'in sonradan adı "Topkapı" olan Romanos Kapısı'ndan şehre girmesiyle, Bizans dönemi sona ermiştir. Fetihle birlikte İstanbul surlarının emniyeti sağlama görevi de bir anlamda son bulmuştur. Bununla beraber İstanbul'un fethinden sonra Fatih Sultan Mehmed 1458'de, surların tamamını onartmıştır. Bundan sonra da deniz tarafindaki surlar II. Bayezid ve IV. Murad zamanında kısmen, III. Ahmed zamanında ise tamamen tamir görmüştür. ${ }^{7}$ Bununla beraber Osmanlı Devleti'nde surlar, Bizans Dönemi'ndeki kadar stratejik önem taşımaz. Zîra Osmanlı Devleti, Batı'dan gelecek tehlikeye karşı kendini korumak bir yana, bizzat kendisi fetihlerinin yönünü Batı'ya

kanlarının ismine atfen inşa ettikleri Bizantion Surları'dır. Şehrin surları bugünkü Saray-Burnu'ndan başlayıp Ayasofya ile Sultanahmet'i birbirinden ayıran yere kadar uzanmaktaydı. (İbrahim Kafesoğlu, İslam Ansiklopedisi (İA), V, 1145) Tarihî yarımadada varlığı bilinen başka bir sur Septimius Surları'dır. Roma imparatoru Septimus Severus, kendisine üç yıl direnen Byzantion'u MS.196'da ele geçirdikten sonra kendi adıyla anılan surları inşa ettirmiştir. Bu surlar bugünkü Yeni Camii (Eminönü) civarından başlayıp, güneye doğru ilerleyerek Çemberlitaş’a çıkıyor buradan güneye Marmara Denizi'ne doğru iniyor, daha sonra Çatladıkapı olarak isimlendirilecek olan bölgeyi de geçerek sahil şeridinde Üsküdar'ın karşısına gelecek bir noktada nihayet buluyordu. (Metin Ahunbay-Zeynep Ahunbay Dünden Bugüne İstanbul Ansiklopedisi, VII, 75)

Eski İstanbul'un aynı sınırları içinde inşa edilen bir diğer sur da Konstantinius Surları'dır. MS. 330 yılında Büyük Konstantin (d.272-ö.337), Septimius Surları'nı yıktırmış yerine daha sonra kendi ismiyle anılacak surları inşa ettirmiştir. Bu surların geçtiği yerler ana hatlarıyla bilinmektedir. Buna göre bu surlar bugünkü Samatya'dan başlıyor, buradan Çukurbostan'a varıyor oradan Bayrampaşa Deresi'ne iniyor oradan Yavuz Selim Camii civarına çıkıyor oradan da kuzeydoğu istikametinde bugünkü Cibâli semtinde nihayet buluyordu. (Kafesoğlu, "İstanbul", s.1145)

Yukarıda adı geçen surlardan hiçbiri günümüze ulaşmamıştır. Bizim, bugün ayakta kalan k1sımlarına şahit olduğumuz surlar, II. Theodosius (MS. 408-450) zamanında yapılmıştır. MS. 395 yılında Roma imparatorluğu, Doğu ve Batı olarak ikiye ayrıldığında Konstantinopolis, Doğu Roma'nın başkenti olmuştur. Bu tarihlerde şehir Gotlar ve Hunlar'ın tehdidi altında bulunmaktadır. Devlet adamlarının görüşleri doğrultusunda şehrin etrafına düşman taarruzuna karşı, daha sonra imparatorun adıyla anılacak olan, Theodosius Surları inşa edilmiştir. (Kafesoğlu, “İstanbul”, s.1145)

1870-1873 yılları arasında Sirkeci Garı'nın yapımı sırasında Topkapı Sarayı civarındaki surların bir kısmı yıkılmıştır. UNESCO, Taç Vakfı ve İstanbul Belediyesi işbirliği ile 1980 yılından itibaren surların restorasyonu aralıklarla devam etmektedir. (Feride İmrana Altun, İstanbul'un 100 Roma, Bizans Eseri, İstanbul 2009, s. 152)

7 Kafesoğlu, "İstanbul”, s.1145

YIL: 5 SAYI: 10 
çevirmiştir.

İstanbul surları 7,5 km kara surları, $5.5 \mathrm{~km}$ Haliç surları, 9 km Marmara Surları olmak üzere toplam $22 \mathrm{~km}$ uzunluğundadır. Eremya Çelebi'nin çağdaşı olan Evliya Çelebi'nin Yedikule'den başlayıp yine Yedikule'de tamamladığı ölçümlerine göre İstanbul surlarının çevresi, kale üzerinden 29.810 adım, sur dışından ise 30.000 adımdır. ${ }^{8} \mathrm{Bu}$ da yaklaşık olarak 22 km'ye tekabül etmektedir.

Surlarla çevrili bir şehre giriş ve çıkış, surların topografik yapısına uygun olarak iktisadî ve askerî önem arz eden noktalarına açılan kapılarından sağlanmaktaydı. Dolayısıyla yerleşim, ticarî hayat ve günlük hayatın akışı buralarda kendini göstermekteydi.

İstanbul surları üzerindeki kapılar kara sınırındaki, Haliç ve Marmara sahilindekiler olmak üzere üç grupta tasnif edilmektedir. ${ }^{9}$ Ancak İstanbul kapılarından bazılarının fetihten sonra kapatılması, bazılarının daha sonra tekrar açılması ve pek çoğunun isimlerinin değiştirilmesinden dolayı yerleri ve sayıları konusunda tereddütler meydana gelmiştir. ${ }^{10}$

XVII. yüzyılda yaşayan Eremya Çelebi Kömürciyan'ın varlı̆̆ına bizzat şahit olduğu kapılar ile Evliya Çelebi'nin İstanbul'un kapıları hakkında verdiği malumat, bilgilerin birbirini desteklemesi açısından önemlidir. ${ }^{11}$

8 Evliya Çelebi, Evliya Çelebi Seyahatnâmesi, Orhan Şaik Gökyay (hzl.), İstanbul 1996, I, 23

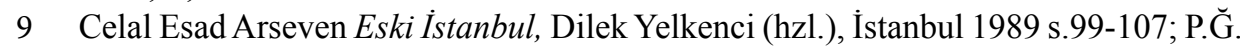
İnciciyan, XVIII. Asırda İstanbul, Hrand Andreasyan (çev), İstanbul 1956, s.10-12

10 İhtifalci Mehmed Ziya Bey, İstanbul ve Boğaziçi, Murat A. Karavelioğlu (hzl.), İstanbul 2003, I, 265

11 Evliya Çelebi, gezisine Yedikule'den başlayarak önce kara sınırındaki kapıları zikreder. Burada Yedikule, Silivrikap1, Yenikap1 (Mevlevihane Kap1s1), Topkap1, Edirnekapı ve Eğrikapı olmak üzere altı kapı vardır ve bunlar batıya, Edirne tarafına bakmaktadır.

Eğrikapı'dan sonra Eremya Çelebi’nin eserinde bahsetmediği kapılar; Eyyüb-i Ensari Kapıs1, Balat Kapıs1, Fanus Kapısı (Fener Kapıs1), Petro Kapısı, Yenikap1, Aya Kapı, Cibâli Kapısı, Unkapanı, Ayazma Kapısı, Odunkapı, Zindan Kapı, Balıkpazarı Kapısı, Yeni Cami Kapısı, Şehid Kapısı (Çıfıt Kapısı) olup toplamda on dört kapıdır. Bunlar kuzeye açılır ve Haliç kıyısındadırlar.

Çıfıt Kapısı'ndan itibaren Marmara sahilindeki kapılar başlar. Bunlar Ahır Kapı, Çatladı Kapı, Kumkapı, Langa Kapısı, Davutpaşa Kapısı, Samatya Kapısı ve Narlıkapı 
Eremya Çelebi, eserini, zamanın meşhur Ermeni âlimlerinden Bitlis'teki Amırdolu Vank Manastırı'nın Başrahibi Vardepet Vardan'ın isteği üzerine yazmış ve eserini ona ithaf etmiştir. Eser bir bakıma XVII. yüzyıl için İstanbul'un seyahat rehberi niteliğindedir. Müellif, "Efendim, büyük Vardepet size hürmet ve selamlarımı takdim ederek, sizinle beraber cenuptan başlamak üzere şehirde bir gezintiye çlkalım " ifadeleriyle güya misafiri olan Vardepet Vardan'a giyabî olarak İstanbul'u gezdirmektedir.

Eremya Çelebi, misafirini -yedi tepe ${ }^{12}$ üzerine kurulu bir şehir dediği İstanbul'u- sur dışından gezdirmeye Yedikule'den başlar, şehrin etrafını dairevî bir şekilde gezdikten sonra gezisini yine burada sonlandırır.

Müellif sur dışından şehri tasvir ederken, şehrin kapılarını esas alır. Kap1 ismini zikrettikten sonra semt ve sakinleri hakkında genel bilgiler verir. Eremya Çelebi'ye göre İstanbul'un sahilden ve karadan toplam yirmi altı kapısı vardır. Yazar, kapıların tanıtımına Yedikule'den başlamak yerine yakınındaki Narlı Kapı'dan başlayıp, Yedikule'yi sona bırakır.

\section{İstanbul Sur Kapıları}

1.Narlı Kapı: Eremya Çelebi’nin aktardığına göre bu kapı, vaktiyle burada nar ağaçları bulunduğu için bu isimle anılmaktaydı. Fakirlerin ikametgâhı olan Zügüurt Yaylası da bu civardaydı. Fakirler, buradaki meyhanelere gelenlerden dilenmek suretiyle geçimlerini sağlarlardı. ${ }^{13}$

Narlı Kap1, Yedikule'den sonra Marmara sahili boyunca devam eden surların ilk kapısıdır. Bu kapı, İstanbul surlarının en eski kapısı olup Bâb-l

olmak üzere toplamda yedi tane olup doğuya bakmaktadırlar. (Evliya Çelebi, Seyahatnâme, I, 23)

12 İstanbul'un yedi tepesi şunlardır: 1.Üzerinde Ayasofya bulunan Akropolis. 2.Bugünkü Çemberlitaş'ın bulunduğu tepe. 3.Bugün İstanbul Üniversitesi binası ve Bayezid Camii'nin bulunduğu tepe. 4.Fatih Camii'nin bulunduğu tepe. 5.Yavuz Selim Camii'nin bulunduğu tepe 6.İstanbul'un en yüksek tepesi olan bugünkü Edirnekapı'nın olduğu tepe. 7.Lykos (Bayram Paşa Deresi) Vadisi'nin sağ tarafında Ayios Mokios Sarnıcı ile bugünkü Çukurbostan’ın bulunduğu tepe. (Kafesoğlu, “İstanbul” s.1149)

13 Eremya Çelebi Kömürciyan, İstanbul Tarihi, Hrand D. Andreasyan (çev), İstanbul 1952, s.2

YIL: 5 SAYI: 10 
Atîk olarak da isimlendirilmektedir. ${ }^{14}$ Burada eskiden Hagios İonnes Studius Kilisesi bulunmaktaydı. Bu kilise, II. Bayezid'in İmrahoru İlyas Bey tarafından camiye çevrilerek İmrahor Camii adını almıştır. ${ }^{15}$ Kapının yanındaki kulenin üzerindeki kitâbeden İmparator Manuel Komnenos tarafindan yapıldığı anlaşılmaktadır. ${ }^{16}$

2.Samatya Kapısı: İskelesi de olan bu kapının bulunduğu yerde Ermenilerin Sulu Manastır'ı ile Balıklı Ayazması vardı. Samatya Kapısı'nın civarında bin hâneden fazla Ermeni yaşamaktaydı. Ayrıca burası şehrin ana yolu üzerinde yer aldığından pek güzel bahçeli meskenler mevcuttu. ${ }^{17}$

Bu kapının eski adı Yunancada "kumluk" veya "sahil" anlamlarına gelen "Psamathia veya "Psamathea" olup, Osmanlı devrinde de aynı isimle anılmıştır. ${ }^{18}$

Sulu Manastır'ın, İstanbul Ermeni cemaatinin kuruluş tarihiyle bağlantısı vardır. Şöyle ki: Fatih Sultan Mehmed, İstanbul'u fethedip Rum Patrikliği'ni tesis ettikten sonra yakından tanıdığı Bursa Ermeni Piskoposu Ovakim'i bazı Ermeni aileleriyle birlikte İstanbul'a getirtmiş ve onu 1461 y1lında Ermeni patrikliğine tayin etmiştir. Ayrıca İstanbul'daki Ermeni cemaatini çoğaltmak için memleketin çeşitli yerlerinden Ermeni ailelerini pâyitahta naklettirmiştir. Fatih Sultan Mehmed gelen Ermeni cemaatini şehrin başlıca altı mevkiine yerleştirmiştir. Bu cemaatin en mühimmi Samatya'da Sulu Manastır Kilisesi'nin etrafında bulunduğundan patriklik makamı da burada kurulmuş ve Kumkapı'ya nakledildiği tarih olan 1641 senesine kadar orada kalmıştır. ${ }^{19}$

3.Davudpaşa Kapısı: Küçük Vlanga Bostanı' nın bulunduğu bu yer, Yenikapı'ya kadar iki kat surlarla çevrili olup bu bölgede Rumlar oturmaktayd1. "Vlanga" Rumcada "yeşillik" anlamına gelmektedir. ${ }^{20}$ Bu kapı-

14 İhtifalci Mehmed Ziya Bey, age, II, 17

15 Kömürciyan, age, s.75, mütercimin notu

16 Arseven, age, s.107

17 Kömürciyan, age, s.3

18 İnciciyan, age, s. 10

19 Kömürciyan, age, s.80, mütercimin notu

20 Kömürciyan, age, s.3 
nın Bizans devrindeki adı Aya Emilianos'tur. ${ }^{21}$ Vaktiyle bu kapı yakınında Hz. Meryem adına yapılmış bir kilise bulunmaktaydı. ${ }^{22}$

4.Yenikapı: Büyük Vlanga Bostanı burada yer almaktaydı. Bu bölgeden Kumkapı'ya kadar olan saha, Ermeni ve Rum mahallelerinin sınırını çizmekteydi. ${ }^{23}$

Vlanga (Langa), Bizans Dönemi'nden itibaren, Haliç’ten sonra şehrin en mühim limanı olmuştur. Bu liman Lycus Deresi (Bayrampaşa Deresi)'nin getirdiği kum ve çakıllarla dolmuş bir süre sonra da bostanlık arazi olarak kullanılmaya başlanmıştır. Langa isminin menşei hakkında farklı görüşler olmakla birlikte Grek halk dilinde "deniz limanı” anlamına gelen “avlaka” zamanla Vlanga’ya dönüşmüştür. Bu kapıya Yenikapı denmesinin sebebi fetihten sonra tamir edilmiş olmasıdır. ${ }^{24}$

İnciciyan, bu isimle anılan bir kapı daha olduğu için bu kapının adına "dışarı" kelimesi ilave etmek lazımdır demektedir. ${ }^{25}$

5.Kumkapı: İbrahim Han Ocağı denilen konak buradaydı. Bunun biraz ilerisinde şehzadelerin oturdukları saray bulunmaktaydı. Karşıda saraya ait katırların beslendiği Katırhanı vardı. Burası, eskiden Kadırga Limanı meydanı idi. Meydan, tahta kulübelerde oturan çingene (Roman) çilingirlerle meskûndu. Fakat Sadrazam Köprülü bu kulübeleri yıktırmış ve çingeneler başka yerlere dağılmıştır. ${ }^{26}$

Kumkap1, şehrin nüfus bakımından en yoğun yerlerinden birisiydi. Fetihten önceki adı "Küçük İskele" anlamına gelen "Kondoskali" idi. ${ }^{27}$ Kumkap1, Bizans döneminde önemli bir liman bölgesi olup bu liman 1263 'te Michel Paleologos zamanında yeniden inşa edilmiştir. ${ }^{28}$

6.Çatladıkapı: $\mathrm{Bu}$ kapının karşısında çatlamış bir burç vard1. Arkasında Küçük Ayasofya denilen güzel bir bina görülmekteydi.

21 İnciciyan, age, s.10.

22 İhtifalci Mehmed Ziya Bey, age, II, 8

23 Kömürciyan, age, s.3

24 Kömürciyan, age, s. 85, mütercimin notu

25 İnciciyan, age, s. 10

26 Kömürciyan, age, s.3-4

27 İnciciyan, age, s. 10

28 İhtifalci Mehmed Ziya Bey, age, II, 10

YIL: 5 SAYI: 10 
Buradaki bostanı geçtikten sonra surun altında Cindi $^{29}$ meydanı denilen geniş bir saha bulunmaktaydı. Cuma günleri birçok insan süratli atlarıyla burada cirit oynarlardı. Yarış esnasında atlar düşüp yuvarlanır ve birbirini çiğnerlerdi. Biniciler, atların altında kalır, gözleri patlamış ve hurdahaş olmuş bir halde "vay vay" diye bağırarak evlerine dönerlerdi. ${ }^{30}$

İnciciyan, bu kapının eski adının "demir" anlamına gelen "sidera" olduğunu nakletmektedir. ${ }^{31}$ Demirkapı denmesinin sebebi ise Büyük Konstantin'in Roma'dan Konstantiniye'ye nakledilen somaki sütunu Çemberlitaş Meydanı'na nakletmek üzere gemiden karaya çıkardıkları vakit aşırı ağırlığından dolayı yolu çökertmesin diye güzergâha bir nevi demir yolu yaptırmış olmasındandır. ${ }^{32} \mathrm{Bu}$ kapının yanındaki burç 1532 yılında meydana gelen depremde çatladığ 1 için kapıya Çatladıkapı denilmiştir. $^{33}$

7.Ahırkapı: Kapı saray ahırlarının tam karşısında olduğu için bu isimle anılıyordu. Karşısında Sultanahmet Camii görülmekteydi. Altı minareli olan bu camii, Atmeydanı'na bakmaktaydı. Meydanda Büyük Theodos tarafından diktirilen Grek ve Latin yazılı yekpâre âbideler vardı. Aynı şekilde Leon Sophos'un yılanları uzak tutmak için tılsım olarak yaptırdığı bakırdan yapılmış üç başlı ve ağızları açık yılan âbidesi de bu meydandadır. Bu iki âbideden daha yüksek ve taştan örme diğer bir âbide daha vardır ki padişahlar, buna tırmanıp tepesine kadar çıkabilenlere bahşiş verirlerdi. İbrahim Paşa'nın adını taşıyan saray, bu camiin tam karşısındaydı. Galatasarayın' da olduğu gibi bu sarayda da iç oğlan ${ }^{34} l a r$ otururdu. Büyük

29 Cindi: "Cündi” kelimesinin galatı olup, binicilikte maharetli olan kimseler hakkında kullanılan bir tabirdir. Bu kimseler, sert huylu atları terbiye etmek için çeşitli usullerle idman yaparlar bunun için de hususi dersler alırlardı. Daha sonra bu becerilerini İstanbul'daki bazı meydanlarda gösterirlerdi. Bazen saray önlerindeki meydanlarda gösteriler yaparlar, yüksek başarı gösterenler padişahtan takdir görürler ve çeşitli mükâfatlarla ödüllendirilirlerdi. (Mehmet Zeki Pakalın, Osmanlı Tarih Deyimleri ve Terimleri Sözlüğü, İstanbul 1993, I, 318)

30 Kömürciyan, age, s.4

31 İnciciyan, age, s. 10

32 İhtifalci Mehmed Ziya Bey, age, II, 14

33 Arseven, age, s.106

34 İç Oğlanı: Osmanlı Devleti’nde saray hizmetine alınıp devletin çeşitli makamlarına aday olarak yetiştirilen gençler hakkında kullanılan bir tabirdir. (Pakalın, age, II, 29) 


\section{$324 \cdot$ YALOVA SOSYAL BILIMLER DERGISI}

İustinianos'un yaptırdığı meşhur Ayasofya da bu meydandadır. Ayrıca burada kubbe pencereleri kapanmış bir arslanhâne vardı. Vaktiyle bir kilise olan bu bina, o dönemde fil, tilki, kurt, çakal, ayı, arslan, timsah, pars ve kaplan gibi hayvanlarla doluydu. Biraz yukarıda ise nakkaşhâne $e^{35}$ yer almakta olup burada sarayın nakkaşları otururdu. ${ }^{36}$

Bizans sarayının ahırlarının özellikle imparator III. Mikhael (842867)'ın atlarının barındığı ahırın da bu civarda olduğu bilinmektedir. Osmanlıların, ahırlarını selefleri olan Bizanslıların ahırlarının olduğu yere inşa etmeleri oldukça tabiidir. Ahırkapı'nın günümüzdeki görünümü Osmanlı Dönemi'ne aittir. Kapının üzerindeki mermer kitâbede Nevşehirli İbrahim Paşa tarafından surların yeniden inşa edildiğine dair bilgiler vardir. ${ }^{37}$

8.Bahçekapısı: Eremya Çelebi'nin aktardığına göre Padişah Sarayı (Topkapı Sarayı)'nın kapısına yakınlığından dolayı bu isimle anılmaktadır. Kapının yanında Bursa Tekkesi olarak da bilinen Şeyh Mehmed Tekkesi yer almaktaydi.

Sahil kısmında, saray için kesilen koyunların mezbahası vardı. Meydan iskelesi olan bu yer, saraya odun taşıyan gemilerle doluydu. Daha ilerde Üsküdar yakasına ve Bitinya (İzmit) taraflarına gidip gelen gemilerin iskelesi yer almaktaydı. Az daha ileride ise Misır ile uzak-yakın adalardan gelen gemiler durmaktaydı. Gümrük ambarlarının da bulunduğu bu yere Eminogi (Eminönü) denmekte olup mallar buraya boşaltılır ve buradan gemilere yüklenirdi. Bu işlerin kontrolünden sorumlu Gümrük Emîni burada ikamet etmekteydi. Yine burada oturan bir de Pencik Emini ${ }^{38}$ var-

35 Osmanlılar Dönemi'nde kitaplara boyalı resim yapan; ipek, ibrişim ve yünle elişi işleyip binalarda yağlı boya ya da suluboya işleri yapan sanatkârlara nakkaş denilmekteydi. Kitaplara minekâri resimler yapmak eski Yunanlılar ve Romalılarca bilinmekteyse de en yaygın olduğu devir Orta Çağ'dır. Nakkaşlık, Doğu'da İranlılar tarafından ilerletilmiş ve usta Acem sanatkârları tarafından pek çok nakışlı kitap meydana getirilmiştir. İran nakkaşlarından Şahkulu Nakkaş, Kanunî Sultan Süleyman zamanında İstanbul'a gelerek Sarayı Âmire'de bir nakkaşhâne (nakışhâne) vücûda getirmiştir. (Pakalın, age, II, 649)

36 Kömürciyan, age, s. 4-5

37 İhtifalci Mehmed Ziya Bey, age, II, 23

38 Pencik Emîni: Lügat manası, "beşte bir" demek olan pencik, askerlikte kullanılmak

YIL: 5 SAYI: 10 
dı ki onun görevi de esir ticaretine nezâret etmekti. Denizin bu kısmında Galata'dan Tophane'ye kadar olan karşı sahile kayıklar işlerdi. ${ }^{39}$

İnciciyan'ın “gece ve gündüz açık kalan kapı” olarak tanımladığı bu kapının Bizans devrindeki adı "Baziliki" veya "Eugeni" dir. ${ }^{40}$ Bizans devrinde "Neori" olarak da bilinen bu kapı, Venediklilerle Bizanslılar'ın mahallelerini ayırıyordu. ${ }^{41}$ Türkler bu kapıya Yahudi mahallesinin yakınında oluşundan dolayı "Yahudi Kapısı veya Çıfıt Kapısı" demişılerdir. Eminönü ile Sirkeci arasında Yeni Camii'nin hemen arkasında yer aldığı bilinen bu kapı Sirkeci Garı'nın inşası esnasında yıktırılmış olup günümüze kadar gelememiştir. $^{42}$

9.Balıkpazarı Kapısı: Bu kapının Bizans devrindeki adı "Porta Perama" idi. Kapının önü eski zamanlarda balık pazarı idi. Venediklilere ait olan bu semt o zaman da ticarî bakımdan önem taşımaktaydı $1 .{ }^{43}$ Nitekim Eremya Çelebi'nin konuyla ilgili aktardıklarına göre burada üç iskele vard. Bunların birinden karşı yakaya sefer yapan kayıklar, diğerlerinden ise köylere giden kayıklar işlemekteydi. Avlanılan her türlü balık buraya getirilir ve buradan satışa çıkarılırdı. Yüz kadar cinsi olan balıkların adları Türkçe ve Rumca idi. Rengârenk balıklar ortaya serildiğinde bir çiçek bahçesini andırıyordu. Balıkpazarı Kapısı'nın karşısında Mısır veya Yeni denilen çarşıların kapıları görünmekteydi. Kurşunla örtülü kubbeleri olan bu çarşının içinde Mısır'ın bütün mahsulleri satılırdı. Kapının bulunduğu mahalde Yahudilere ait yüz kadar kasap ve manav dükkanı vardı. Daha ileride iki tarafta kunduracı dükkanları bulunur, diğer dükkanlarda ise rengarenk yaldızlı ibrikler ve kâseler satılırdı. ${ }^{44}$

Beylik Arpa Ambarı burada olup Arpa Emîni'nin makamı da buradayd1. Bahçekapı'dan Unkapanı'na kadar olan sahil, adalardan, Akdeniz'den

üzere savaşlarda ele geçen esirlerin beşte birinin alınmasıdır. Pencik Emini ise, esir pazarlarında satılan köle ve cariyelerden alınan vergi alımlarıyla meşgul olan memura verilen isimdir. (Pakalın, age, II, 766-777)

39 Kömürciyan, age, s.15-16

40 İnciciyan, age, s. 10

41 Arseven, age, s.105

42 Kafesoğlu, "İstanbul”, s.1148

43 Kömürciyan, age, s.166, mütercimin notu

44 Kömürciyan, age, s.16 
ve İzmit'ten gelen gemilerle daima doluydu. Mısır Çarşısı'nın karşısında kahvecilerin tahmis ${ }^{45}$ i, bir yanında da muazzam bir camii vardı ki bu camiyi Valide Sultan Turhan yaptırmıştır. ${ }^{46}$

Haliç'in karşı yakasından Galata'ya geçmek için buradan kayıklara binilirdi ki günümüzde bu kapıdan eser kalmamıştır. ${ }^{47}$

10.Zindankapı: Bu kapı, adını borçlarını ödemeyen, hırsız, katil, vb. suçluların cezalarını çektikleri buradaki hapishaneden almaktadır. Eremya Çelebi hapishane ile ilgili olarak "Burada kadinların; Türk, Rum, Ermeni ve Yahudi erkeklerin yerleri ayrı ayrıdır" ifadelerini kullanırken kapının iç tarafında "Cafer Baba" isimli bir zatın türbesinin varlığından da haber vermektedir. ${ }^{48}$

Müellifin aktardığına göre bu kapının sahilinde türlü türlü kuru ve yaş yemişler satan dükkanlar vardı. Bundan dolayı da buradaki iskeleye "Yemiş İskelesi" denilmekteydi. Ayrıca buradaki esnafa ve alış verişe nezâret eden Muhtesib A $\breve{g} a^{49}$ da buraya yakın oturmaktayd..$^{50}$

Kumkapı'dan başlayıp Bayezid Camii'nin $100 \mathrm{~m}$ batısından geçip Haliç'e varan yol Zindankapı ile bitiyordu. Bu kapının diğer adı "Gemiciler Kapısı" idi. Günümüzde bu kapı harap durumdadır. ${ }^{51}$ Evliya Çelebi'nin rivayetine göre kapıya bu ismin veriliş sebebi Halife Harun Reşid zamanında Bizans imparatoruna elçi olarak gönderilen Baba Cafer adında bir zâtın burada hapsedilerek öldürülmesi ve buraya defnedilmesi-

45 Tahmis: Kavrulmuş ve dövülmüş kahve satılan yerler hakkında kullanılan bir kelimedir. Yakın zamanlara kadar kullanılan bu kelimenin yerine günümüzde "kuru kahveci" terimi kullanılmaktadır. (Pakalın, age, III, 375)

46 Kömürciyan, age, s.16

47 Kafesoğlu "İstanbul", s.1148

48 Kömürciyan, age, s.17

49 Muhtesib Ağa: Osmanlı şehir merkezlerinde günlük hayatın tanziminde, özellikle esnaf teşekküllerinde satılan malın kalitesini, fiyatını ve ölçülerinin kontrolünü yapmak ve kanunlara uygun davranmayanları cezalandırmak başta olmak üzere, İslam dininin hoş karşılamadığı şeyleri ortadan kaldırmak ile insanları iyiye yöneltmeye çalışmakla vazifeli kimsedir. (Pakalın, age, II, 572: Ayrıca konuyla ilgili bilgi için bkz. Ziya Kazıcı, Osmanlılarda İhtisab Müessesesi, İstanbul 1987)

50 Kömürciyan, age, s. 17

51 Altun, age, s.161-162

YIL: 5 SAYI: 10 
dir. ${ }^{52}$ İnciciyan'ın naklettiği bilgiye göre bu türbe o dönemde Hiristiyanlar tarafından da ziyaret edilmekteydi. ${ }^{53}$ İstanbul'un fethinden sonra türbenin olduğu yer hapishane olarak kullanılmıştır. Rivayete göre borcu yüzünden zindana atılanlar, pencerelerden bağırarak borçlarının ödenmesini isterler, bazen hayırseverler bunların borçlarını ödeyerek onları zindandan kurtarırlarmış. ${ }^{54}$

11.Odunkapısı: Eremya Çelebi'den edindiğimiz bilgiye göre İstanbul'un bütün kapılarının tam ortasında bulunan bu kapının eşiği somaki cinsinden yekpâre bir taştır. Kapının yakınında Âhi Çelebi Camii ${ }^{55}$ ile bir de mahkeme vardı. Hasımlar arasındaki davalar burada görülürdü. Kap1 önündeki iskele, gemilerden boşaltılan inşaat malzemeleriyle doluydu. Deniz kıyısındaki surun yanlarında eşya ile dolu dükkanlar vardı. Ayrıca eşkıya ve hırsızlar burada çengele vurulurdu. ${ }^{56}$

Odunkapısı'nın adı Bizans devrinde "Durungari” veya yanında bulunan emniyet kolluğuna izafeten "Viglae" idi. Bu sahilde Büyük İustinianus zamanında kereste ticareti yapılmaktayd..$^{57}$ Evliya Çelebi'nin verdiği bilgiye göre bu kapının iç kısmında mumcu esnafı bulunuyordu. ${ }^{58} \mathrm{Kap}$ günümüze kadar gelememiştir. ${ }^{59}$

12. Ayazmakapısı: Eremya Çelebi, bu kapı ve civarı hakkında "Burada bazı yalılar görülür. Bu evleri zengin Türkler yaptırmış ve Yahudilere kiralamışlardır. Terlikçi ve zeytinci dükkanları bulunan bu semt satıcı ve alıcılarla daima doludur. Tekfurdă̆ (Tekirdă̆) gemileri Gelibolu iskelesinden buraya bol miktarda pekmez, turşu ve müselles getirirler ${ }^{60}$

52 Evliya Çelebi, Seyahatnâme, I, 32

53 Inciciyan, age, s. 11

54 Altun, age, s.161-162

55 Âhi Çelebi Camii: Fatih Sultan Mehmet, Sultan II. Bayezit, Yavuz Sultan Selim ve Kanuni Sultan Süleyman devirlerinde yaşamış ve iki defa hekimbaşılık yapmış olan Âhi Çelebi Mehmed tarafından 1480-1500 yılları arasında yapıldığı tahmin edilmektedir. Kanlı Fırın Mescidi olarak da bilinen bu cami günümüzde İstanbul Ticaret Üniversitesi (Eminönü) yakınındaki Yoğurtçular sokağındadır.

56 Kömürciyan, age, s. 17

57 Kömürciyan, age, s.169, mütercimin notu

58 Evliya Çelebi, Seyahatnâme, I, 243; 256

59 Altun, age, s.161

60 Kömürciyan, age, s.17 
demektedir.

"Drungari Kapısı" olarak da zikredilen bu kapının arkasında Venedikliler Mahallesi ile onlara ait Marc ve Sainte Marie Kiliseleri vardır. ${ }^{61}$ Kapının bu isimle anılması, kapı yakınında çukurca bir yerde su kaynağının bulunması ve ayazma olarak ziyaret ediliyor olmasındandır. ${ }^{62}$

13.Unkapanı Kapısı: Şimdi Unkapanı denilen on üçüncü kapıya vard $k$ diyen Eremya Çelebi, üstünde bir horoz şekli bulunan bu kapıya eskiden "Horozlu Kapı" denildiğini belirtmektedir. ${ }^{63}$

Evliya Çelebi'ye göre bu kapıya "Horozlu Kapı" denmesinin sebebi, Ahmed Yesevî erenlerinden olup çok ilerlemiş yaşına rağmen İstanbul'un fethine katılan Horozî Dede lakaplı bir zâtın kapının iç tarafında medfun olmasındandır. Bu lakapla anılmasının sebebi ise fetih sırasında her ezan vaktinde horoz sesi çıkararak insanlara namazı hatırlatmasıdır. Bu zatın hatırasına binaen bu kapının üzerine horoz tasviri yapılmıştır. ${ }^{64}$

Eremya Çelebi'nin aktardığına göre burada imâretlerin fodla ${ }^{65}$ 'sına ve softa ${ }^{66} l a r$ ile askerlerin tayin ${ }^{67}$ ine mahsus kurşunlu kapan yani büyük un dükkanları olup ekmekçiler unu buradan temin etmekteydi. Kapının iskelesinde duran gemiler kuzeyden çok miktarda un getirirlerdi. Kapı önündeki iskele darı, arpa ve buğday yığınları ile dolu olup ayrıca iskelede değirmen taşı, alât edevât, kepek ve saman taşıyan birçok kayık bulunmaktayd1. ${ }^{68}$

İstanbul'da halkın ihtiyacı olan ekmek yüz on kadar fırında pişirilirdi. Bundan başka firınlarda çörek, kata, kadayıf, baklava, simit, gevrek, pek-

61 Arseven, age, s.105

62 İhtifalci Mehmed Ziya Bey, age, I, 308

63 Kömürciyan, age, s.18

64 Evliya Çelebi, Seyahatnâme, I, 38

65 Fodla: Yassı pide şeklinde yapılan bir çeşit ekmek. (Pakalın, age, I, 634)

66 Softa: Halk arasında medrese talebesi için kullanılan bir tabirdir. Medrese talebelerinin ilim aşkıyla yanmalarından kinaye olarak önceleri "suhte" olarak kullanılan bu kelime daha sonraları tahrife uğrayarak "softa” şeklini almıştır. (Pakalın, age, III, 252)

67 Tayin: Askere verilen erzak ve yiyecek anlamına gelmektedir. (Pakalın, age, III, 426)

68 Kömürciyan, age, s.18

YIL: 5 SAYI: 10 
simed, lavaş, çakıl fodla, Halep ve Şam böreği, gözleme, francala, yağlı ve yağsız taze kuru lokma da pişirilirdi. Ekmekçiler kahyası, buradaki alış verişe nezâret ettiği gibi İstanbul Efendisi ${ }^{69}$ 'nin burada ikamet eden nâib (vekil) i de bütün gün kayıtlarla meşgul olurdu. Büyük çoğunluğu Ermeni olan ekmekçi ustaları pazar ve cuma gününün dışında her gün erkenden Lonca' da hazır bulunurlard1. ${ }^{70}$

Deniz gümrüğüne nezâret eden Balık Emini de burada ikamet ederdi. Kılıçbalığı, Karadeniz'den buraya getirilir Balık Emini'nin nezareti altında İstanbul'daki balıkçılara dağıtılırdı. Biraz ileride de tüfek imal edilen bir tüfenghâne vard1. ${ }^{71}$

Unkapanı'nın Bizans devrindeki adı "Porta Platea” dır. Kapı, bugünkü Unkapanı Köprüsü (Gazi Köprüsü)'nün yakınında bulunan bir meydana açılmaktayd1. ${ }^{72} \mathrm{Bu}$ kap1 günümüze ulaşamamıştır.

14.Cibâli Kapısı: Bu kapının iki tarafında evlerle birlikte Aya Nikola adında bir Rum kilisesi vardı. Bu kiliseden dolayı burada Yahudilerle ile pek çok Rum ikamet etmekteydi. İskelesi, civar halkının bütün ihtiyaçlarını karşılayacak her türlü mahsulatla doluydu. Pek çok insan buradaki sahile gezmeye gelirdi. ${ }^{73}$

İstanbul'un fethi sırasında Cübbe Alî veya Cebe Alî adındaki bir gazinin bu kapı önünde şehit olmasından dolayı galat olarak bu kapıya Cibâli Kapı denmiştir. ${ }^{74}$ Cibâli Kapısı, Haliç Surları'nın günümüze gelen tek kapısıdır. Burası İstanbul'un fethine tanık olmuş en eski kapılarından biridir. $^{75}$

15.Ayakapısı: Eremya Çelebi’ye göre sadece bu kapının iskelesi yoktur. Bu kapının suru içerlektir. Sahilinde bir mumhânesi olan bu kapı-

69 İstanbul Efendisi: İstanbul kadıları hakkında kullanılan bir tabirdir. H. 1000 (M. 1591) yıllarından sonra kullanılmaya başlanmış daha sonraları terkedilmiştir. (Pakalin, age, II, 92-93)

70 Kömürciyan, age, s. 18

71 Kömürciyan, age, s.19

72 Kömürciyan, age, s.169, mütercimin notu

73 Kömürciyan, age, s.19

74 Evliya Çelebi, Seyahatnâme, I, 38

75 Altun, age, s.161 
nın inzibatından sorumlu bir kolluk bulunmaktaydı. ${ }^{76}$

Kapının bu isimle şöhret bulmasının sebebi, yakınında Aya Theodosia adında bir kilisenin varlığıdır. Adından da anlaşılacağı üzere civarda bulunan ve bir azize ithaf edilen bir mabedin varlığından dolayı kapıya bu isim verilmiştir. Bu kilisenin yortusu 29 Mayıs'tır. Rivayete göre 1453 yılının aynı gününde kadınlı erkekli büyük bir halk kitlesi geceyi kilisede ibadetle geçirmiş ertesi gün bu kalabalık ellerinde mumlarla evlerine giderken esir düşmüşlerdir. ${ }^{77} \mathrm{Bu}$ kilisenin Osmanlı döneminde camiye çevrildiği ve Gül Camii olarak isimlendirildiği yönünde rivayetler varsa da bu konuda kesin bir bilgi yoktur. ${ }^{78} \mathrm{Bu}$ kapı günümüze kadar gelememiştir. ${ }^{79}$

16. Yenikapı: Müellifin kaydettiğine göre bu kapının önünde sandallarla dolu bir iskele vardi. Sultan Mehmed ve Sultan Selim semtlerinin halkı buraya gelirdi. Konak ve bahçe sahibi okumuş efendiler denizde sandal gezintileri yapmak için buraya inerlerdi. ${ }^{80}$

Cibâli Yeni Kapısı olarak da bilinen bu kapı, İstanbul'un fethinden sonra açılmıştır. ${ }^{81}$ İnciciyan bu kapıyı Marmara sahilindeki Yenikapı'dan ayırmak için "İçeri Yenikapı" dendiğini nakletmektedir. ${ }^{82}$

17.Petro Kapısı: Surun burada açık olduğunu söyleyen Eremya Çelebi, kapıdan içeri girildiğinde surun iki kat olduğunu belirtmektedir. Sahilde sıra sıra Rum evleri olup surun dâhilinde yani kapının iç tarafında Rum zâdegânı ikamet etmekteydi. ${ }^{83}$

"Petrikapısı" da denilen bu kapı fetihten sonra da aynı isimle anılmaya devam etmiş̧ir. Bizans devrinde burada imparator ailesine mensup kadınlardan bazılarının da kaldığı "Petriler" veya "Petra" adı verilen kadınlar manastırı vardı. ${ }^{84}$ Günümüzde kapıya dair herhangi bir kalıntı bu-

76 Kömürciyan, age, s.19

77 İhtifalci Mehmed Ziya Bey, age, I, 313

78 Semavi Eyice, "Gül Camii” DİA, XIV, 223

79 Altun, age, s. 162

80 Kömürciyan, age, s.19

81 İhtifalci Mehmed Ziya Bey, age, 313

82 İnciciyan, age, s.11

83 Kömürciyan, age, s.19-20

84 İhtifalci Mehmed Ziya Bey, age, I, 315

YIL: 5 SAYI: 10 
lunmamaktadir. ${ }^{85}$

18.Fener Kapısı: Eremya Çelebi’nin aktardığına göre bu kapının iç ve diş tarafinda Rumlar oturmaktaydı. Buradan kuzeye doğru Hasköy, Okmeydanı ve padişaha ait bir bahçe görülmekteydi. Kapının iç kısmında Patrikhâne bulunmaktaydı. Patrikhane, o zamana kadar üç defa yer değiştirmişti. İlk yer Büyük Konstantin zamanında inşa edilmiş Havariyun Kilisesi idi. Sultan Mehmed İstanbul'u fethettikten sonra kiliseyi temelinden yıktırıp yerine kendi adını verdiği bir camii yaptırmıştır. Patriklik makamı az aşağıda bulunan Panmakariston adlı kiliseye taşınmış, fakat bu kilise de Sultan Selim zamanında Rumların elinden alındığı için patriklik makamı Fenerkapısı'ndaki bugünkü yerine nakledilmiştir. ${ }^{86}$

Bu kapının eski adı "Porta Phari” olup Türkçede "Fener" anlamına gelmektedir. Kapının yakınındaki mahalle Bizans devrinde "Fanari” olarak isimlendirilmekteydi Limanın bu kısmında, o zamanlar bir fener olduğu tahmin edilmektedir. ${ }^{87}$ Kap1 günümüze kadar gelememiştir. ${ }^{88}$

19. Balat Kapısı: Eremya Çelebi'den edindiğimiz bilgilere göre Ayvansaray'a doğru olan bu kapının dış tarafında Yahudiler, iç tarafında ise çeşitli milletlere mensup kalabalık bir halk kitlesi ikamet etmekteydi. O dönemde Yahudiler, İstanbul'un her yerinde sahile yakın yerlerde oturmaktaydılar. Burada yaşayan Yahudilerin nüfusu Hasköy, Beşiktaş, Ortaköy, Kuruçeşme, Kuzguncuk, Üsküdar ve Çengelköy'den daha çoktu. Aynı zamanda burası büyük bir iskele olup eşya yüklü gemiler buraya yanaşırdı. Ayrıca buradan Kağıthane'ye ve İstanbul'un diğer semtlerine sandallar işlemekteydi. ${ }^{89}$

İstanbul'un fethinden sonra yapılmış olan ve “Küçük Ayvansaray Kapısı" olarak da isimlendirilen bu kapıya civarındaki Bizans sarayından dolayı bu adın verildiği tahmin edilmektedir. Bizans müelliflerince "Porta Kiliomene" denilen kapının Ayvansaray İskelesi'nin yerinde olduğu riva-

85 Altun, age, s. 160

86 Kömürciyan, age, s.20

87 Kömürciyan, age, s.176, mütercimin notu

88 Altun, age, s. 160

89 Kömürciyan, age, s.20-21 
yet edilmektedir. ${ }^{90}$ Evliya Çelebi, İstanbul'un dört yerinde şişeci esnafi yani cam eşya yapan esnaf olduğunu söyledikten sonra bunlardan birinin de Ayvansaray Kapısı önünde olduğunu nakleder. ${ }^{91}$ Bu kapı günümüze gelememiştir. ${ }^{92}$

20.Ayvansaray Kapısı: Bu kapı civarında -zenginleri sahilde olmak üzere- Yahudiler oturuyordu. Kapının iç kısmında, ayazması da olan Vlahernas Pania isimli harap bir kilise vardı. Sandallar buradaki iskeleden Eyüpsultan'a gidip gelirlerdi. Burada, şişelerin ve camdan türlü türlü kapların yapıldığ kârhâneler yer almaktayd.$^{93}$

Eremya Çelebi'nin eserinde zikretmediği Ayvansaray'dan sonra Xyloporta isimli bir kapı daha vardır. Bu kapı Haliç sahilinde Vlakherna Sarayı'na en yakın kapı idi. Evliya Çelebi'nin Eğrikapı'dan sonra “Eyyüb-i Ensari”" adı ile zikrettiği kapı bu olsa gerektir. ${ }^{94}$

Buraya kadar bahsi geçen kapılar, şehrin sahil kapılarıdır. Eremya Çelebi, buradan sonraki gezisine İstanbul'un kara kapılarını yani sahili olmayan altı kapısı ve semtlerini tanıtarak devam eder. Nitekim hayali misafiri Vardapet Vardan'ı buradan itibaren kayıkla değil de atla gezdirir. Eremya Çelebi'nin Vardapet Vardan'1 gezdirdiği kapılar şunlardır:

21.Eğrikapı: Bu kapının iki kısmı tam karşılıklı olmadığı için Eğrikapı denmiştir. Eğri Kapı'nın olduğu yerde sur iki kattı. Buradan Eyüp'e kadar olan bölgede Topçular ve diğer köyler vardı. Müslüman mezarlığı Ayvansaray'dan buraya kadar uzanmaktaydı. Su dolu hazne buraya yakın olup Sultan Süleyman tarafindan getirilmiş olan bol su, itina ile yapılmış müteaddit su yolları ile şehrin çeşmelerine ulaşmaktaydı. Su, altı saat uzakta bulunan yüksek dağlardan kemerler vasitasıyla getirilmekteydi. Burada iki büyük havuzun ağzına kefgir (kevgir, süzgeç) ler konulmuştu. Su merkezinin üstünde bulunan köy ahâlisi, suyu temiz tutmak ve daima ona nezaret etmekle sorumluydu ${ }^{95}$

\footnotetext{
90 Kömürciyan, age, s.180, mütercimin notu

91 Evliya Çelebi, Seyahatnâme, I, 288

92 Altun, age, s.160

93 Kömürciyan, age, s.21

94 Kömürciyan, age, s.181, mütercimin notu

95 Kömürciyan, age, s.22
}

YIL: 5 SAYI: 10 
Eremya Çelebi'nin sözünü ettiği su haznesi, Kırkçeşme Suyu'nun şehre girdiği mevkide bulunan maksim ${ }^{96}$ olup, "Savaklar" adıyla da bilinmektedir. Bu maksem, Kanuni Sultan Süleyman zamanında Mimar Sinan tarafından inşa edilmiştir. Bu mahalle Savaklar Mahallesi olarak bilindiği gibi Cebeci Mahallesi olarak da anılmaktayd1. ${ }^{97}$

Eğrikapı'nın Bizans devrindeki adı "çarık" anlamına gelen "Kaligaria" idi. Kapının yakınında bir askerî ayakkabı imalathânesi bulunduğu için kapıya bu ad verilmiştir. ${ }^{98}$ Evliya Çelebi'ye göre ise fetihten sonra Anadolu'dan İstanbul'a getirilen ve bu semte yerleştirilen Eğridirliler'den dolay1 kapı, bu ismi almıştır. ${ }^{99}$ Diğer bir rivayete göre ise Osmanlı Dönemi'nde kapıdan içeri girilmeden önce yol keskince bir dirsek yaptığı için kapıya Eğrikapı denilmiştir. Kapı günümüzde varlığını korumaktadir. ${ }^{100}$

22. Edirnekapı: Eremya Çelebi’ye göre burada Türklere ait bahçeler, konaklar ile Bayram Paşa'nın bostanı vardı. İç taraflarda ise Beylik Çayırı ile Yeni Bahçe yer almaktaydı Bunların yakınında, kapının dâhilinde ise Karagümrük semti bulunuyordu. ${ }^{101}$

Edirnekapı'nın Bizans devrindeki adı "Porta Charsius" idi. Surların Edirnekapı ile Topkapı arasındaki kısmı İstanbul'un fethinde önemli bir rol oynamıştır. Zîra İstanbul'un fethi esnasında en şiddetli hücumlar surların alçak bulunduğu bu noktadan yapılmıştır. Bundan dolayı bu kapıya "Hücum Kapısı" da denilmiştir. Fetihten önce de Edirne'ye buradan gidildiği için Bizans döneminde burası Edirnekapı olarak biliniyordu. ${ }^{102}$ Bizans imparatorları gibi Osmanlı padişahları da Avrupa'ya sefere giderken bu kapıyı kullanırlardı. Ayrıca tahta çıkan padişahlar Eyüp Sultan’da kılıç ku-

96 Maksim: Su kaynaklarından şehre gelen suları evlere, çeşmelere ve hamamlara vb. yerlere taksim (dağıtmak )için havuz ve tekneleri olan üstü örtülü su haznesine verilen isimdir. Halk arasında bu kelime maksem olarak kullanılmaktadır. (Pakalın, age, II, 394)

97 İhtifalci Mehmed Ziya Bey, age, I, 326

98 Kafesoğlu, "İstanbul", s.1147

99 Evliya Çelebi, Seyahatnâme, I, 45

100 Altun, age, s. 158

101 Kömürciyan, age, s.23

102 İhtifalci Mehmed Ziya Bey, age, I, 149 


\section{$334 \cdot$ YALOVA SOSYAL BILIMLER DERGISI}

şandıktan sonra şehre bu kapıdan girerlerdi. Osmanlı döneminde buraya Rumeli'den getirilen esnafın yerleştirildiği bilinmektedir. Günümüzde var olan kapının kulesi 1999 depreminde yıkılmış o tarihten sonra restorasyon çalışmaları yapılmıştır. ${ }^{103}$

23. Topkapı: Eremya Çelebi'nin kaydettiğine göre kapının önüne fetih alâmeti olarak toplar konulmuştu. Kapının iç ve dış tarafinda poşa (çingene) lar oturuyordu. Poşaların erkekleri elek yapar, kadınları da bunları satmak için sokak sokak dolaşırlardı. Poşaların pek çoğu o dönemde Müslüman olmuştu. Ayrıca Edirne'ye yük götürüp getiren Ermeni katırc1lar da burada ikamet etmekteydi. Kapının sağ tarafında Davudpaşa Konağı vardı. Konak ve civarı çok güzel olduğundan Paşa, haremiyle buraya eğlenmeye ve dinlenmeye gelirdi. ${ }^{104}$

Rum çingenelerle meskun Litros da buradaydı. Bu çingenelerin kadınları hânende olup evlerde ve sokaklarda şarkı söylerlerdi. Eremya Çelebi eserinde, Ermenilerle Rumlar herhangi bir mevzudan dolayı münakaşaya girdiklerinde "bizim poşalar ekmeklerini alın terleriyle kazanırlar; hâlbuki sizinkiler ellerinde dablak (küçük davul veya darbuka) larla şarkı söyleyerek zevk ticareti yaparlar" diyerek Rumları küçük düşürmeye çalıştıklarını yazmaktadır. ${ }^{105}$

Eremya Çelebi'nin sözünü ettiği Davutpaşa, Bizans Dönemi'nde "Aretai" olarak isimlendirilmekteydi. Burada imparatora ait köşkler vard. Osmanlı Dönemi'nde ise çok mühim bir askeri toplanma sahası olup Rumeli güzergâhına giden ordular burada toplanırdı. Burası aynı zamanda ordunun uğurlanma ve karşılanma noktasıydı. II. Bayezid'in damadı Davudpaşa 1483 yılında burada bir camii, bir mektep ve bir de imarethâne inşa ettirmiştir. Burada daha sonra padişaha ait köşkler ile bir kışla yaptırılmıştır. ${ }^{106}$

Topkapı'nın Bizans Dönemi’ndeki adı, civarında bulunan bir kiliseye

103 Altun, age, s. 158

104 Kömürciyan, age, s. 24

105 Kömürciyan, age, s. 24

106 Kömürciyan, age, s.190, mütercimin notu

YIL: 5 SAYI: 10 
izafeten St. Romen Kapısı'dır. ${ }^{107}$ Bu kapıya Topkapı denilmesinin sebebi ise fetih esnasında topların bu kapı önüne yerleştirilmiş olmasıdır. ${ }^{108}$ İstanbul'un fethi sırasında Fatih Sultan Mehmed'in çadırı bu kapının karşısındaki tepeye kurulmuştu. Bizans'ın son İmparatoru XI. Konstantin de Topkapı'nın iç taraflarında yapılan çarpışmada öldürülmüşsür. ${ }^{109}$

Topkapı, Millet Caddesi'nin yapımı sırasında yıkılmıştır. Ancak yan duvarları üzerindeki küçük bir tâlî kapı kalmış, caddenin iki tarafındaki surlar ise onarılmıştır. ${ }^{110}$

24. Yenikapı: Bu kapının yakınında Beylik Barut Ambarları ve muhafızları bulunuyordu. Kapının yakınındaki bahçelerin içinde derviş odaları ve bir Mevlevîhâne vardı. Ayrıca bu kapının yakınlarında bir baruthâne ${ }^{111}$ ile birlikte Ekanim-i Selâse (Aya Triada) isimli bir de Rum ayazması yer almaktayd1. ${ }^{112}$

Bu kapının, Bizans Dönemi’ndeki adı "Rhegium" dur. Bu kapıya "Rus Kapısı" veya "Kırmızı Firka Kapısı" da denilmekteydi. ${ }^{113}$ Bizans Dönemi'nde hipodromda yapılan araba yarışlarında mavi, yeşil ve kırmızı renkli takımlar vardı. İşte bu kapı, kırmızılar tarafından inşa edildiği için bu adı almıştır. Kapının iç tarafında bu takıma mensup olanların ismi vardır. "Yenikapı" adının ise fetihten sonra Osmanlılar Dönemi'nde kullanıldığı anlaşılmaktadır. Bu adın kaynağı tam olarak bilinmiyorsa da kapının muhasara zamanında Bizanslılar tarafından kapatılıp, fetihten sonra açılmiş olduğu tahmin edilmektedir. ${ }^{114}$

XVI. yüzyılda Sultan III. Murad zamanında Merkez Efendi isimli hak dostunun burada bir Mevlevî tekkesi kurmasından dolayı bu kapıya aynı zamanda Mevlevîhâne Kapısı da denilmiştir. Kapı günümüze kadar ulaş-

107 İhtifalci Mehmed Ziya Bey, age, I, 129

108 Arseven, age, s. 102

109 Kömürciyan, age, s.189, mütercimin notu

110 Altun, age, s. 157

111 Evliya Çelebi Tophâne, Selânik, Belgrad ve Mısır'dan gelen barutların, Yenikapı'da sur duvarları içindeki mahzenlerde depolandığını yazmaktadır. (Evliya Çelebi, Seyahatnâme, I, 257)

112 Kömürciyan, age, s.24

113 Arseven, age, s.102

114 İhtifalci Mehmed Ziya Bey, age, I, 122 - 124 
miştır. ${ }^{115}$

25. Silivrikapı: $\mathrm{Bu}$ kapının iç tarafında bir cami ve bir hamam yer almaktaydı. Kapının dışında Elekçi Dede ${ }^{116}$ 'nin mezarı vardı. Eremya Çelebi'nin aktardığına göre bu zat, hiç konuşmayan elekçilerin peşinde gezen bir kimsedir. Onun bu kadar uzun süre konuşmamış olması, hayrete mucip olmuştur. Sadece bir defa konuştuğu ve "Azizim beni niçin bu kadar rahatsız ediyorsun? Allah'ın bir kulu ve dindar bir Müslüman var mı ki konuşayım ve selam vereyim" demiştir. Bu rivayet, onun halk nazarındaki itibarını arttırmıştır. Ölmeden önce pek çok insanın rüyasına girerek kefenini 1smarlamıştır. O kadar ki Melek Ahmed Paşa'nın dahî rüyasına girmiş ve kefeni Paşa tarafından gönderilmiştir. Elekçi Dede için büyük bir cenaze merasimi yapılmış, mezarının üzerine de bir türbe yaptırılmıştır. İşaret ve alâmet olsun diye de bir elek asılmış olup hastalar şifa bulmak, çocuğu olmayan ya da erkek çocuk isteyen kadınlar da istediklerine nâil olmak için Elekçi Dede'nin mezarını ziyaret etmektedirler. ${ }^{117}$

Eremya Çelebi'nin aktardığına göre bu kapının iki tarafında Müslüman mezarlıkları yer alıyordu. Biraz ileride ise "Balıklı" denilen Rum ayazması görülüyordu. Burası daha önce "Panaia" adlı bir manastırdı. Ayrıca burada Balıklı Ermeni Mezarlığı da bulunmaktaydı. ${ }^{118}$

Bu kapı Bizans Dönemi'nde de aynı isimle anılmaktaydı. Kapıya, "Selivria" (Silivri) ya giden yolun başında bulunduğu için bu isim verilmiştir. Bu kapıdan Balıklı Ayazması'na gidildiği için kapı "Porta Pighi" olarak da bilinmekteydi. ${ }^{119}$

26. Yedikule Kapısı: Bu kapının yakınında tokat ${ }^{120}$ denilen bir hendek vardı. Halkın kışın tüketecekleri et ihtiyacı için sığırlar burada satılır, bu hayvanların etinden pastırma yapılırdı. Daha ileride ise salhâneler bu-

\section{Altun, age, s. 156}

116 Elekçi Dede: Alemdar Eba Eyyüb-i Ensari Muslihiddin isimli bir zat olup Silivrikapı'nın dış tarafının sağında medfundur. (İhtifalci Mehmed Ziya Bey, age, I,117; Ayrıca bu zat hakkında bilgi için bkz. Evliya Çelebi, Seyahatnâme, I, 163)

117 Kömürciyan, age, s.24-25

118 Kömürciyan, age, s. 25

119 Kömürciyan, age, s.192, mütercimin notu

120 Tokat: Kale içi, siper, ahır ve ağıl için kullanılan bir kelimedir. (Pakalın, age, III, 510)

YIL: 5 SAYI: 10 
lunmaktaydı. Kasaplar, hayvanları burada geceleyin keser ve sabahleyin dükkanlara dağıtırlardı. Şehirde sığır eti satan yüzden fazla dükkan vardı. Rumlar üç yüz civarındaki dükkanlarında koyun eti satarlardı. ${ }^{121}$

Çeşitli dükkanların, hanların ve debbağhânelerin bulunduğu Kazlıçeşme, bu kapı civarındaydı. Bu ismi almasının sebebi bir kazın yeri eşelemesi ve oradan bir suyun çıkmasıdır. Daha sonra buraya bir çeşme yapılmıştır. ${ }^{122}$

Biraz ileride deniz kıyısında Aziz Pantaleyimon'un adına ithaf edilmiş Makrahora ${ }^{123}$ (Makriköy, Bakırköy) Ayazması ve İskender Çelebi'nin bahçesi görülmekteydi. Burası şehirden bir saat kadar uzakta bir sahil köyü idi. Aynı yerde taşlık denilen bir mevkiden de taş çıkarılmaktaydı. Bu sahilde Ayistifan (Aystefanos, Yeşilköy)'a kadar güzel köyler vard1. Daha ileride bir ziyaretgâh olan kilisesi ve ayazması ile Kalatarya, bunun yanında da Filurya (Florya) adında padişaha ait güzel bir bahçe yer almaktayd1. Ağustos ayı içinde Uruc-ı Meryem ${ }^{124}$ yortusu gününde şehrin Rum ve Ermenileri oraya ziyarete giderlerdi. ${ }^{125}$

Bu kapının eski adı "Beş Kule" anlamına gelen "Pentapyri Pyle" idi. Başlangıçta beş kulesinin olduğu diğer iki kulenin ise 1350 senesinde inşa edildiği bilinmektedir. ${ }^{126}$ Bizans zamanında halkın geçişi için yapılmış olan bu kapı Yedikule Hisarı'na bitişiktir. ${ }^{127}$ Evliya Çelebi, Yedikule ile ilgili olarak "Bizans zamanında buranın nazarete yani karantina bölgesi olup veba şüphesine kaşı dişarıdan gelen kimselerin burada yedi gün tu-

121 Kömürciyan, age, s. 28

122 Kömürciyan, age, s. 28

123 Makrahora (Makriköy, Bakırköy), Bizans döneminde "Hebdomon” olarak adland1rılıp Balkanlar'dan başkente gelen yol üzerinde olduğundan dolayı önem arz etmekteydi. $\mathrm{Bu}$ özelliğinden dolayı buraya imparator sarayları, kiliseler ve diğer birçok abidevi eserler yapılmıştı. Bölge, genişliği ve bol suyu sayesinde aynı zamanda askerî bir karargâh olarak da kullanılıyordu. Büyük depremlerde halk buraya koşar ve tehlike geçinceye kadar burada barındırılırdı. (Kömürciyan, age, s.203, mütercimin notu )

124 Uruc-1 Meryem: Hıristiyanlara göre Meryem Ana'nın “göğe yükseliş” günüdür. Ağustos ayının 15'ine en yakın pazar günü kutlanmaktadır.

125 Kömürciyan, age, s.28-29

126 Arseven, age, s.102

127 İhtifalci Mehmed Ziya Bey, age, I, 109 
tulduğunu yazmaktadır. Fatih Sultan Mehmed zamanında ise bütün derici esnafı burada iskân edilip mezbahalar da buraya toplanmıştır. ${ }^{128}$

Yedikule Kapısı'nın hemen yanı başında Eremya Çelebi döneminde kapalı bulunup kullanılmayan Yaldızlı Kapı mevcuttu. Bizans döneminde "Porta Aurea" olarak bilinen bu kapı I. Theodoius zamanında Maximus'a karşı kazanılan zafer şerefine inşa edilmiştir. Yaldızlı Kapı, cilalı mermer blokların harçsız olarak birbirine geçirilmesi suretiyle yapılmıştır. ${ }^{129}$

Yaldızlı kapı, resmî günlerde imparatorların ve askerlerin geçmesine mahsus bir kapıydı. Bundan dolayı halk buradan geçemezdi. ${ }^{130}$ Nitekim I. Theodoius zamanından itibaren zaferden dönen veya Hebdomon (Bakırköy)'daki Ayios İonnis Kilisesi'nde taç giyen imparatorlar, ihtişam1 bir alayla Yaldızlı Kapı'dan şehre girer, askerlerin ve halkın tezahüratları arasında uzun bir yoldan geçerek Ayasofya'ya gelirlerdi. Askerî bakımdan da önem arz eden bu kapının iki tarafinda metin kulelerden başka önünde geniş bir hendek bulunuyordu. Sultan Yıldırım Bayezid zamanındaki İstanbul muhasarasında bu kapı zorlanmıştır. Varılan antlaşmada Sultan Bayezid, kapıya yapılan ilave istihkâmların yıktırılmasını şart koşmuş ve bu istek yerine getirilmiştir. İstanbul'un fethi esnasında bu kapının karş1sina muhasara aletleri ve bir top yerleştirilmiştir. ${ }^{131} 1960$ y1lında restore edilen bu kap1, günümüzde Yedikule Hisarı içinde yer almaktadır. ${ }^{132}$

\section{Sonuç}

İlk ve Orta Çağlarda şehirlerin güvenliği, çevresine sur adı verilen kuleli sağlam duvarlarla sağlanırdı.

Özellikle Doğu Roma ve onun devamı niteliğindeki Bizans İmparatorluğu Dönemi'nde başkent olan Konstantinopolis (İstanbul) d1şarıdan gelebilecek düşman saldırılarına karşı müstahkem surlarla korunmuştur. Bu surlar, dönemin imparatorları tarafından, şehrin genişlemesi,

128 Evliya Çelebi, Seyahatnâme, I, 166

129 İhtifalci Mehmed Ziya Bey, age, I, 94

130 Arseven, age, s.100

131 Arseven, age, s.100

132 Altun, age, s. 153

YIL: 5 SAYI: 10 
düşman saldırılarından zarar gören surların yerine yenilerinin yapılması gibi sebeplerle inşa edilmiştir. Müdafaadan ziyade taarruz merkezli bir siyaset takip eden Osmanlı Dönemi'nde ise bu surlar stratejik önemini yitirmiştir.

Etrafı surlarla çevrili bir şehrin giriş ve çıkışları, surların uygun noktalarına inşa edilen kapılarla sağlanmaktaydı. Dolayısıyla bu kapıların civarı iktisadî ve sosyal hayatın en canlı olduğu yerlerdir. İstanbul surları üzerindeki kapılar kara sınırındakiler, Haliç ve Marmara sahilindekiler olmak üzere üç gruba ayrılmaktadır. Kapı isimleri ve sayıları gerek bazılarının fetihten sonra kapanması veya açılması gerekse isimlerinin değiştirilmesi gibi sebeplerden dolayı dönemlere göre farklılıklar göstermektedir.

Eremya Çelebi, eserinde tarihî yarımada üzerindeki surlarda yirmi altı kapının varlığından haber vermektedir. Yazar sıralamaya Marmara sahilindeki Narlı Kapı'dan başlar ancak buradan Haliç'e doğru devam etmek yerine kara sınırına doğru çıkar daha sonra Haliç sahilindekileri sayarak Marmara sahiline iner ve başladığı noktada bitirir.

Eremya Çelebi eserinde kapıların isimlerini, kapının şeklinden veya üzerindeki bir sembolden; civarındaki camii, kilise, ayazma gibi kutsal mekânlardan; yakınındaki tarihî şahsiyetlerin mezarlarından veya hatıralarından; kapının bulunduğu yerin coğrafi yapısından veya kapının etrafında gerçekleşen iktisadî faaliyetlerden aldığını ifade etmektedir.

Eremya Çelebi'nin, kapıların yakınındaki Roma, Bizans ve Osmanlı Dönemi'nde inşa edilmiş olan tarihî eserler hakkında verdiği bilgiler, kültür ve sanat tarihine kaynaklık etmesi bakımından önem taşımaktadır.

Eremya Çelebi, eserinde sadece kapıların isimlerini vermekle kalmayıp kapı yakınındaki semt sakinlerinin etnik yapısı, dinî hayatı, alışkanlıkları, örf ve adetleri ile geçim kaynakları hakkında bilgiler vermekte böylece XVII. yüzyıl Osmanlı Devleti'nin sosyo-kültürel hayatına 1şık tutmaktadır. Ayrıca kapıların yakınındaki semtler ile limanlarda gerçekleşen ticaret, imalât sanayi, esnaf teşekkülleri gibi Osmanlı Devleti'nin iktisadî hayatı hakkında bizzat şahit olduğu bilgileri aktarıyor olması onu birincil kaynak yapmaktadir. 
$340 \cdot$ YALOVA SOSYAL BILIMLER DERGISI

\section{Kaynaklar}

Ahunbay, Metin-Ahunbay, Zeynep, Dünden Bugüne İstanbul Ansiklopedisi,

Kültür Bakanlığı ve Tarih Vakfı Ortak Yayını, İstanbul 1994, VII

Arseven, Celal Esad Eski İstanbul, Dilek Yelkenci (hzl.), Çelik Gülersoy Vakfı İstanbul Kütüphanesi Yayınları, İstanbul 1989

Evliya Çelebi, Evliya Çelebi Seyahatnâmesi, Orhan Şaik Gökyay (hzl), Yapı Kredi Yayınları, İstanbul 1996, I

Eyice Semavi "Kale”, Diyanet İslam Ansiklopedisi, İstanbul 2001, XXIV

Eyice Semavi, “Gül Camii” Diyanet İslam Ansiklopedisi, İstanbul 1996, XIV

İhtifalci Mehmed Ziya Bey, İstanbul ve Boğaziçi, Murat A. Karavelioğlu (hzl.), BİKA Kültür Kitaplığı Yayınları, İstanbul 2003, I, II

İmrana, Altun, Feride, İstanbul'un 100 Roma, Bizans Eseri, İstanbul Belediyesi Kültür A.Ş Yayınları, İstanbul 2009

İnalc1k, Halil "İstanbul”, Diyanet İslam Ansiklopedisi, İstanbul 2001, XXIII

İnciciyan P.Ğ., XVIII. Asırda İstanbul, Hrand Andreasyan (çev.), İstanbul Fethi

Derneği İstanbul Enstitüsü Yayınları, İstanbul 1956

Kafesoğlu, İbrahim "İstanbul” İslam Ansiklopedisi, Milli Eğitim Bakanlığ1 Yayınları, İstanbul 1987, V

Kós, Károly, İstanbul: Şehir Tarihi ve Mimarisi, Naciye Güngörmüş (çev.), Kültür Bakanlığ Yayınları, Ankara 1985

Kazıcı, Ziya, Osmanlılarda İhtisab Müessesesi, İstanbul 1987

Kömürciyan, Eremya Çelebi, İstanbul Tarihi, Hrand D., Andreasyan (çev), İstanbul 1952

Pakalın, Mehmet Zeki Osmanlı Tarih Deyimleri ve Terimleri Sözlüğ̈̈, Milli Eğitim Bakanlığı Yayınları, İstanbul 1993, I, II, III

Yılmazer, Ziya, “Eremya Çelebi”, Diyanet İslam Ansiklopedisi, İstanbul 1995, XI

YIL: 5 SAYI: 10 